\title{
Measuring Digital Literacy Skills Among Students in Senior High School
}

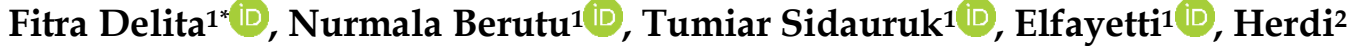 \\ ${ }^{1}$ Department of Geography Education, Faculty of Social Sciences, Universitas Negeri Medan, Sumatera Utara, Indonesia \\ 2Department of Economics Education, Faculty of Teacher Training and Education, Universitas Muslim Nusantara \\ AlWashliyah, Medan, Indonesia
}

\section{ARTICLE INFO}

Article History:

Received: December 30, 2021

Revision: January 22, 2022

Accepted: January 24, 2022

Keywords:

Digital Literacy

E-Learning

Learning Media

Percut Sei Tuan

Medan

Corresponding Author

E-mail: fitradelita@unimed.ac.id

\begin{abstract}
Various digital-based learning media strongly support the quality of online learning. Digital media is essential in the learning process because it can package the material into more contextual, interesting audiovisual, reduces verbalism, and is more interactive. The primary purpose of this research was to measure the differences in digital literacy by comparing the digital learning media and PowerPoint media in online learning. The design of this study was a pretest-posttest group with a quasi-experimental method. Overall, 56 students in a senior high school in Senior High School 2 Percut Sei Tuan, Medan City, Sumatera Utara Province, served as participants in this study. Data were collected by questionnaires and structured interviews for digital literacy. Data analyses were mixed with the quantitative and qualitative methods. Quantitative data were analyzed statistically through independent samples t-test, and qualitative data were analyzed descriptively. Digital literacy data were analyzed using SPSS version 24 software. The results showed that the students' digital literacy using digital learning media was superior to those prepared using PowerPoint. Based on each aspect of digital literacy, namely, internet searching, understanding, and utilizing digital devices, hypertextual navigation, content evaluation, creating digital content, and communicating information, there were significant differences between groups on digital literacy competencies. All aspects of digital literacy in the experimental class were higher than in the control class.
\end{abstract}

\section{INTRODUCTION}

The integration of technology in education is one of the main requirements for learning in the 21st-century. Educators who master various learning technologies are appropriate for this era where the students are the digital generation (Alexander et al., 2016). Learning in the global pandemic era is dominated by distance learning or, in other words, also addressed e-learning almost all over the world. E-learning is one form of education that utilizes ICT. Habituation, using technology, will undoubtedly improve digital literacy for both teachers and students. The qualifications of educators to use various innovations and ICT in learning will conclude the achievement of education (Sharma, 2017)(Delita, 2021)(Berutu et al., 2019). Integration of technology to improve the quality of education can be defined as the everyday use of information and communications technology (ICT) in the learning process. Educators are essential elements in this sophisticated integration process (UNESCO, 2019)(Sanchez-Prieto et al., 2020)(Al Khateeb, 2017). Several types of research have shown that educators' capabilities and experiences are the essential factors that influence the quality and efficiency of learning(Falloon, 2020) (Sagitaa et al., 2019). One of the uses of technology in education is digital media (Sidauruk et al., 2021). 
Digital learning media such as web, blog, video, and multimedia can be used for all primary, secondary, and higher education subjects. This digital media can be defined as a tools/learning platform or application designed for teaching and learning. Digital learning media can facilitate and stimulate students' cognitive skills with a more meaningful learning experience (Paidi et al., 2021)(Sidauruk et al., 2021). Digital media is essential in the learning process because it can package the material to be more contextual, interesting audiovisual, reduce verbalism, and be more interactive (Rusydiyah, Purwati, \& Prabowo, 2020). Technology-based media uses digital tools needs computers and mobile phones as supporting devices. Using digital learning media also aimed to increase students' writing and computer skills, digital skills, interactive, responsive, and share knowledge to enrich learning experiences and resources (Nelson et al., 2011). Regarding digital learning in the 21st-century, digital media is proposed to improve student engagement involvement enhance knowledge and competencies (Purwadi et al., 2020). The use of digital media in learning is an effort to grow up student interest, motivation, attractiveness, digital literacy, and student learning outcomes.

Digital literacy refers to the learners' skills to search the information on the internet browser and operate various software tools (Buckingham, 2010)(Law et al., 2018). Digital literacy is not only just understanding how to use technology but also knowing beneficial of the tools and when to utilize them (Alexander et al., 2016), having the capability to organize the information, critical and creative thinking skills (Law et al., 2018). There are twenty aspects related to digital literacy as follow: information research and retrieval, information evaluation, learning resources, utilization tools, data transmission, information communication, social responsibility, authorize of digital information, choose appropriate computing devices, systems analysis, system design, tools development, programming, security of data and the information, security of financial and personal identity, administration of the database, data management, networking, computer technology; photography and digital video (Nelson et al., 2011). Aspect of digital literacy competencies include capability in utilizing technology, applying technology to acquire, asses, create, and communicate information (Oh et al., 2021).

There are various studies on digital learning media and digital literacy. Digital learning media such as multimedia can provide students with a more meaningful learning experience to stimulate cognitive abilities (Leach, 2017). Digital media is essential in the learning process because it can direct the material to be more contextual, interesting audiovisual, reduces verbalism and is more interactive (Rusydiyah et al., 2020). (Al Khateeb, 2017) evaluated digital literacy among students in primary secondary school to analyze their opinion toward digital literacy skills and their accomplishment inappropriate digital exercises. (Commission, 2019) investigated how critical elements of digital literacy are to learning outcomes when utilizing the internet as learning resources. (Perdana, Yani, et al., 2019) used tests and surveys to examine digital literacy skills differences between before and after treatment is given. (Bond et al., 2018) investigated the psychometric properties of the recently tested self-report evaluation device for media literacy, based on 12 new media literacy (NML).

This study aimed to measure digital literacy skills among students treated with digital learning media and powerpoint media. The novelty of this research from previous research is web-based media to improve digital literacy. Then this digital learning media was tested on online learning during the COVID-19 pandemic.

\section{RESEARCH METHODS}

This study used a quasi-experimental method with a pretest-posttest group design. The research was conducted 
through 5 meetings $(2 \times 45$ minutes $)$ in online learning using Zoom Cloud Meeting and Whatsapp Group. The study was born about Geography with remote sensing. This topic is one of the most challenging topics for teachers because of the limited media available, especially online learning. The participants were 56 students consisting of the control class as Group A (28 students) and the experimental class as Group B (28 students). This student was randomly selected in Senior High School 2 Percut Sei Tuan, Medan City. The practical course received treatment in digital learning media during the online learning process, while the control class used powerpoint slides.

This research was conducted in the 2021/2022 academic year. At the first meeting, for 60 minutes, students in both groups were given a pretest. This pretest was conducted to measure digital literacy and prior knowledge. At the second to fourth meetings, Group A was taught material using powerpoint slides while Group B used digital learning media in an interactive web. After treatment, students were given a posttest to measure digital literacy. Digital literacy was measured using a questionnaire consisting of 20 questions. Aspects of digital literacy used in this study include internet searching, understanding, and utilizing digital devices, hypertextual navigation, content evaluation, creating digital content, and communicating information (researchers' modification of the digital literacy aspect, which was formulated by experts and then selected and developed indicators according to research objectives).

The structured interviews were purposed for the qualitative data collection. The interview question divided into four dimensions are as follows: opportunities for students when they use the web as digital learning media on Geography subject, incredibly remote sensing sub-topic, the obstacles for students when they use the web as digital learning media on Geography subject, extremely remote sensing sub-topic, opportunities for students when they use slide powerpoint as media on Geography subject, incredibly remote sensing sub-topic, The obstacles for students when they use slide powerpoint as media on Geography subject, extremely remote sensing sub-topic. Seven students in the experimental group and seven students in the control group were chosen for the interview section.

Digital literacy data were analyzed using SPSS version 24 software. Tests on normality and data homogeneity were carried out using the Shapiro-Wilk and Levene tests. The statistical analysis was continued using an independent samples ttest. Independent samples t-test was conducted to examine powerpoint media (control class/ Group A) and digital learning media (experimental class/ Group B) on digital literacy. Meanwhile, interview data were analyzed qualitatively and presented in narrative form. Once the interview was completed, the researcherinitiated sorting transcript and then analyzed using ground theory. The stages of data analysis consisted of reduction, data categorization, data displaying, and concluding.

The measurement of digital literacy uses a Likert scale with the scoring method in the form of 1 point) strongly disagree; 2 points) contradict; 3 facts) neutral; 4 points) agree and 5 points) strongly agree. Three expert teams carried out the instrument validation qualitatively on the construct aspects. Digital literacy instrument reliability was measured using Cronbach's alpha. The Cronbach's alpha value was 0.89 (digital literacy). Based on the results of the analysis, the instruments are declared reliable.

\section{RESULT AND DISCUSSION}

The data of digital literacy were homogeneous invariances; the results of Levene's test were 0.167. An independent sample t-test was conducted to measure learning media's effect between the experimental (digital learning media) and the control group (powerpoint media). The independent samples t-test on the pretest scores for the two groups was insignificant. 
Thus, there were no significant differences in digital literacy between the control and experiment classes (t value $=1.167 ; \mathrm{p}$ value $=0.124$ ) it can be observed in Table 1 .

The independent samples t-test in the posttest scores can be seen in Table 2. Table 2 showed statistically significant differences existed among the two groups on digital literacy, specifically $t$-value $=7.259$ and $p$ value $=0.001$. Regarding their digital literacy scores, the experimental class $(\mathrm{M}=85.39, \mathrm{SD}=6.039)$ was higher than the control class $(\mathrm{M}=75.18, \mathrm{SD}=4.355)$. In other words, the digital literacy of students in the experimental class (taught by digital learning media) was better than the digital literacy of students" in the control class obtained by PowerPoint media regarding
Geography learning. Students' digital literacy skills can be improved if students are familiarized with the use of these technologies such as computers, android, learning websites, and others (Delita, 2021)(Berutu et al., 2019). The development and use of digital learning media will improve students' digital literacy skills (Kamaluddin \& Widjajanti, 2019). An independent samples t-test was also performed to analyze pretest scores for each aspect of digital literacy. The results of the independent samples t-test of each aspect were insignificant. Therefore, no significant differences existed among the two groups on the pretest. The $t$-value for each aspect was $0.42,0.17,0.39,0.08,0.59$ and 0.06 , respectively $\mathrm{p}>0.05$ (see Table 3 ).

Table 1. The result of independent sample t-test of digital literacy on the pretest

\begin{tabular}{ccccc}
\hline Group & Mean & SD & T-Value & P-Value \\
\hline Control & 70.11 & 5.021 & \multirow{2}{*}{1.167} & 0.124 \\
Experiment & 71.89 & 6.356 & & \\
\hline
\end{tabular}

Table 2. The result of independent sample t-test of digital literacy on the posttest

\begin{tabular}{ccccc}
\hline Group & Mean & SD & T-Value & P-Value \\
\hline Control & 75.18 & 4,355 & 7.259 & 0.001 \\
Experiment & 85.39 & 6,039 & & \\
\hline
\end{tabular}

Source: Research finding, 2021.

Table 3. The comparison aspect of digital literacy among two group on pretest

\begin{tabular}{|c|c|c|c|c|c|}
\hline The Aspect of Digital Literacy & Group & $\mathrm{M}$ & SD & T-Value & P-Value \\
\hline \multirow{2}{*}{ Internet Searching } & Control & 1.54 & 0.265 & \multirow{2}{*}{0.42} & \multirow{2}{*}{0.674} \\
\hline & Eksperimen & 1.61 & 0.272 & & \\
\hline Understanding and Utilizing & Control & 1.56 & 0.286 & \multirow{2}{*}{0.17} & \multirow{2}{*}{0.598} \\
\hline Digital Devices & Eksperimen & 1.61 & 0.355 & & \\
\hline \multirow{2}{*}{ Hypertextual Navigation } & Control & 1.35 & 0.356 & \multirow{2}{*}{0.39} & \multirow{2}{*}{0.699} \\
\hline & Eksperimen & 1.60 & 0.559 & & \\
\hline \multirow{2}{*}{ Content Evaluation } & Control & 1.68 & 0.562 & \multirow{2}{*}{0.08} & \multirow{2}{*}{0.941} \\
\hline & Eksperimen & 1.65 & 0.619 & & \\
\hline \multirow{2}{*}{ Create Digital Content } & Control & 1.55 & 0.358 & \multirow{2}{*}{0.59} & \multirow{2}{*}{0.798} \\
\hline & Eksperimen & 1.60 & 0.539 & & \\
\hline \multirow{2}{*}{ Communicate Information } & Control & 1.86 & 0.591 & \multirow{2}{*}{0.06} & \multirow{2}{*}{0.639} \\
\hline & Eksperimen & 1.85 & 0.628 & & \\
\hline
\end{tabular}

Whereas the result of the independent samples t-test in the posttest scores indicated statistically significant differences among the two groups for each aspect. The t-value for each aspect was 20.02, 18.40, $12.60,12.90,9.90$ and 21.90, respectively, 
$p<0.0001$ (See Table 4). Table 4 showed that the scores of students in the experimental class were higher than the scores of students in the control class for all aspects of digital literacy. The use of digital learning media can improve every aspect of digital literacy compared to conventional learning (Delita, 2021)(Sidauruk et al., 2021). However, certain aspects should be of concern, namely producing digital content. Most students are still low on this aspect, where students still have difficulty creating digital content using various software/tools (Perdana, Riwayani, et al., 2019). Not only that, but the ability of students to evaluate information from various digital sources is also important. Students must have the ability to think analytically and critically to filter and assess information both from data accuracy, reliable sources, and usefulness (Sagitaa et al., 2019). This ability will later develop into problem-solving skills.

Table 4. The comparison aspect of digital literacy among two group on posttest

\begin{tabular}{lccccc}
\hline The Aspect of Digital Literacy & Group & $\mathrm{M}$ & SD & T-Value & P-Value \\
\hline \multirow{2}{*}{ Internet Searching } & Control & 2.19 & 0.321 & \multirow{2}{*}{20.02} & $<0.0001$ \\
& Experiment & 3.89 & 0.227 & & \\
Understanding and Utilizing & Control & 2.21 & 0.256 & \multirow{2}{*}{18.40} & $<0.0001$ \\
Digital Devices & Experiment & 3.95 & 0.373 & & \\
Hypertextual Navigation & Control & 2.13 & 0.494 & \multirow{2}{*}{16.60} & $<0.0001$ \\
& Experiment & 3.84 & 0.382 & & \\
Content Evaluation & Control & 1.86 & 0.592 & \multirow{2}{*}{12.90} & $<0.0001$ \\
& Experiment & 2.85 & 0.629 & & \\
Create Digital Content & Control & 1.97 & 0.606 & \multirow{2}{*}{9.90} & $<0.0001$ \\
& Experiment & 2.65 & 0.442 & & \\
Communicate Information & Control & 3.17 & 0.526 & \multirow{2}{*}{21.90} & $<0.0001$ \\
\hline
\end{tabular}

In terms of the analysis of qualitative data, the results of interviews were coded into the dimensions. As a finding, four sizes appeared that were dependable among all the student's responses. The four sizes were as pursue opportunity aspect caused by the use of the web as digital learning media to learn Geography subject, incredibly remote sensing, obstacles aspects caused by the use of the web as digital learning media to learn Geography subject extremely remote sensing, opportunity aspect caused by the use slide powerpoint media to learn Geography subject incredibly remote sensing and obstacles elements generated by the use slide powerpoint media to learn Geography subject, extremely remote sensing. Opportunities for students to study Geography subject by utilizing the web as learning media as follow.
1. After using the web as a learning media, which contains learning materials, tutorials, practice, and online quizzes, I was greatly assisted in mastering the material and enhancing my learning outcomes (Student E)

2. I was attracted to this web because it can be accessed easily through my smartphone (Student B)

3. I felt that learning Geography, incredibly remote sensing topics with the web, was exciting and compelling (Student $\mathrm{F}$ )

4. I could improve my knowledge and skills, specifically in terms of digital literacy (Student C).

The challenges for students to study Geography subject by utilizing the web as learning media include:

1. I felt that looking with web-based learning media was detrimental to 
student's eyes when we have stared at the computer screen for quite a long time (Student D)

2. My internet quota was so wasteful (Student A and Student G)

Opportunities for students to study Geography subject by utilizing powerpoint media include:

1. The material in the powerpoint media can be printed more easily (Student K)

2. I felt powerpoint media was straightforward to use (Student $\mathrm{H}$ and Student N)

The challenges for students to study Geography subject by utilizing powerpoint media include:

1. I lacked digital literacy skills when using powerpoint media (Student I and Student O)

2. I felt bored and monotonous (Student J, Student L, and Student M)

Regarding digital literacy, the experimental group showed significant enhancement. Using digital learning media on the experimental group is more advantageous for digital literacy improvement when compared with using slide powerpoint media on the control group. The result of the study accorded with the findings stated by (Sidauruk et al., 2021) that pointed out that digital literacy can be improved through various treatments such as using digital learning media. In addition, the findings of this study were also consistent with (Perdana, Yani, et al., 2019); after treatment conducted on control and experimental class, they found that there was a siginificant difference in digital literacy both of group where web as learning media is the more effective than a direct method to improving learners digital literacy competencies (Pinto da Mota Matos et al., 2016).

Based on each aspect of digital literacy, namely, internet searching, understanding, and utilizing digital devices, hypertextual navigation, content evaluation, creating digital content, and communicating information, there were differences significant between groups on digital literacy competencies. All aspects of digital literacy in the experimental class were higher than in the control class. The element of creating digital content was the lowest compared to another part. This is due to the limited ability of students to produce digital content and the lack of training related to this ability in various lessons (Perdana, Riwayani, et al., 2019). The aspect of communication was the highest compared to all the elements of digital literacy measured in this study. Students are accustomed to discussions, presentations, and expressing ideas in various learning processes. The ability to communicate information is one of the primary skills needed today and in the future (Liza \& Andriyanti, 2020). Using digital learning media in the experimental group is more effective in enhancing students' learning outcomes when compared with using slide powerpoint media in the control group. Learning outcomes are the achievements of students after participating in the learning process. The learning outcomes include cognitive, affective, and psychomotor aspects (Delita, 2021). Measurement of mental elements can be viewed from students' mastery of the material they have learned. If educators facilitate a more interactive and exciting learning environment for students to improve their skills and learning outcomes (Yustika \& Iswati, 2020), then learning achievement is increased when using digital learning (Akrim, 2018) (Al Khateeb, 2017). Internal factors and external factors determine student learning achievement. Internal factors can be intelligence, interests, capability, and emotional dimension such as passion, behavior, awareness, and desires (Puspita Sari \& Setiawan, 2018). External factors can include physical aspects, school environments such as methods and learning media used by teachers, social elements, and society. External factors have interrelationships with internal factors. 


\section{CONCLUSION}

Digital learning media was effective in improving students' digital literacy. If the teacher uses interactive and exciting learning media, students will be motivated and interested in learning. Thus, student learning achievement will increase cognitive, affective, and skill aspects. So that teachers must improve their ability to master learning technology to produce relevant teaching materials and follow the demands of $21^{\text {st-century learning. }}$

\section{ACKNOWLEDGEMENT}

We are grateful to the Research and Community Service Institute Universitas Negeri Medan for funding this study.

\section{REFERENCES LIST}

Akrim, M. (2018). Media Learning in Digital Era. 231(Amca), 458-460. https://doi.org/10.2991/amca18.2018.127

Al Khateeb, A. A. M. (2017). Measuring Digital Competence and ICT Literacy: An Exploratory Study of In-Service English Language Teachers in the Context of Saudi Arabia. International Education Studies, 10(12), 38. https://doi.org/10.5539/ies.v10n12p 38

Alexander et al. (2016). Living with New Technologies. Scientific American, 273(3), 190-205. https://doi.org/10.1038/scientificam erican0995-190

Berutu, N., Delita, F., Astuti, A. J. D., Novira, N., \& Wirda, M. A. (2019). The Strategy to Strengthen Information Literacy Based on Library and Digital Resources. 208(ICSSIS 2018). https://doi.org/10.2991/icssis18.2019.28

Bond, M., Marín, V. I., Dolch, C., Bedenlier, S., \& Zawacki-Richter, O. (2018). Digital transformation in German higher education: student and teacher perceptions and digital media usage. International Journal of Educational Technology in Higher Education, 15(1), 1-20. https://doi.org/10.1186/s41239-0180130-1

Buckingham, D. (2010). Defining Digital Literacy. Medienbildung in Neuen Kulturräumen, 1, 59-71. https:/ / doi.org/10.1007/978-3-53192133-4_4

Commission, E. (2019). Eurydice 2019:Digital Education at School in Europe. In (C) Education, Audiovisual and Culture Executive Agency, 2019. https://doi.org/10.2797/763

Delita, F. (2021). The Challenges of ELearning Implementation During the Covid-19 Pandemic in Senior High School. Journal of Digital Learning and Education, 1(3), 150-157. https://doi.org/10.52562/jdle.v1i3.25 7

Falloon, G. (2020). The digital teacher competency (TDC) framework is from digital literacy to digital competence. Educational Technology Research and Development, 68(5), 2449-2472. https://doi.org/10.1007/s11423-02009767-4

Kamaluddin, M., \& Widjajanti, D. B. (2019). The Impact of Discovery Learning on students Mathematics Learning Outcomes. Journal of Physics: Conference Series, 1320(1), 709-722. https:// doi.org/10.1088/17426596/1320/1/012038

Law, N., Woo, D., de la Torre, J., \& Wong, G. (2018). A Global Framework of Reference on Digital Literacy. UNESCO Institute for Statistics, 51, 146.

Leach, A. M. (2017). Digital Media Production to Support Literacy for Secondary Students with Diverse Learning Abilities. Journal of Media Literacy Education, 9(2), 30-44. https://doi.org/10.23860/jmle-201909-02-03

Liza, K., \& Andriyanti, E. (2020). Digital literacy scale of English pre-service teachers and their perceived readiness toward digital technologies. Journal of Education and Learning (EduLearn), 14(1), 
https://doi.org/10.11591/edulearn.v $14 \mathrm{i} 1.13925$

Nelson, K., Courier, M., \& Joseph, G. (2011). An Investigation of Digital Literacy Needs of Students. Journal of Information Systems Education, 22(2), 95-109.

Oh, S. S., Kim, K. A., Kim, M., Oh, J., Chu, S. H., \& Choi, J. Y. (2021). Measurement of digital literacy among older adults: Systematic review. Journal of Medical Internet Research, 23(2). https://doi.org/10.2196/26145

Paidi, Subali, B., \& Handoyo, L. D. (2021). The mastery of technological, pedagogical, and content knowledge among Indonesian biology teachers. European Journal of Educational Research, 10(3), 1063-1073. https://doi.org/10.12973/EUJER.10.3.1063

Perdana, R., Riwayani, R., Jumadi, J., \& Rosana, D. (2019). Web-Based Simulation on Physics Learning to Enhance Digital Literacy Skill of High School Students. JIPF (Jurnal Ilmu Pendidikan Fisika), 4(2), 70. https:// doi.org/10.26737/jipf.v4i2.10 48

Perdana, R., Yani, R., Jumadi, J., \& Rosana, D. (2019). Assessing Students' Digital Literacy Skill in Senior High School Yogyakarta. JPI (Jurnal Pendidikan Indonesia), $8(2), \quad 169$. https://doi.org/10.23887/jpiundiksha.v8i2.17168

Pinto da Mota Matos, A., Isabel Festas, M., \& Maria Seixas, A. (2016). Digital media and the challenges for media education. Applied Technologies and Innovations, 12(2), 43-53. https://doi.org/10.15208/ati.2016.04

Purwadi et al. (2020). The Effect of Smartphones Usability on High SchoolSStudents' Science Literacy Ability in Physics Learning. European Journal of Educational Research, 9(3), 1257-1265.

Puspita Sari, A., \& Setiawan, A. (2018). The Development of Internet-Based Economic Learning Media using
Moodle Approach. International Journal of Active Learning, 3(2), 100109.

http://journal.unnes.ac.id/nju/index .php/ijal

Rusydiyah, E. F., Purwati, E., \& Prabowo, A. (2020). How to use digital literacy as a learning resource for teacher candidates in Indonesia. Cakrawala Pendidikan, 39(2), 305-318. https://doi.org/10.21831/cp.v39i2.30 551

Sagitaa, D. D., Asni, Nofriza, F., Fitniwilis, burhendi, F. C. A., \& Siswanto, R. D. (2019).SStudents' digital literacy skills to solve learning problems. International Journal of Innovation, Creativity, and Change, 5(6), 112-122.

Sanchez-Prieto, J., Trujillo-Torres, J. M., Gómez-García, M., \& Gómez-García, G. (2020). The generational digital gap within dual vocational education and training teachers. European Journal of Educational Research, 9(4), 1557-1567. https://doi.org/10.12973/EUJER.9.4.1557

Sharma, M. M. M. (2017). Teacher in a Digital Era. Global Journal of Computer Science and Technology, 17(3), 11-14.

Sidauruk, T., Delita, F., Berutu, N., Elfayetti, E., \& Yenny, N. (2021). The Effect of ELearning on the student's Learning Outcome in Higher Education. 2-5. https://doi.org/10.4108/eai.31-82021.2313756

UNESCO. (2019). Recommendations on Assessment Tools for Monitoring Digital Literacy within UNESCO Digital Literacy Global Framework. Information Paper, 56, 23.

Yustika, G. P., \& Iswati, S. (2020). Digital Literacy in Formal Online Education: A Short Review. Dinamika Pendidikan, 15(1), 66-76. https://doi.org/10.15294/dp.v15i1.23 779 